\title{
Biochemical composition of pigeonpea genotypes in Kenya
}

\author{
Juliana J. Cheboi ${ }^{1,2}$, Miriam G. Kinyua ${ }^{2}$, Paul K. Kimurto ${ }^{3}$, Oliver K. Kiplagat ${ }^{2}$, Fredrick Ng'an'ga $^{4}$ and Sita R. \\ Ghimire $^{4^{*}}$
}

\author{
${ }^{1}$ Department of Plant Science and Crop Protection, University of Nairobi, P.O Box 29053-00625, Nairobi, Kenya \\ ${ }^{2}$ Department of Biotechnology, University of Eldoret, P.O Box 1125-30100, Eldoret, Kenya \\ ${ }^{3}$ Department of Crops, Horticulture \& Soils, Egerton University, P.O Box 536-20115, Njoro, Kenya \\ ${ }^{4}$ Biosciences eastern and central Africa - International Livestock Research Institute (BecA-ILRI) Hub, P.O Box 30709 - \\ 00100, Nairobi, Kenya
}

\section{*Corresponding author: S.ghimire@cgiar.org}

\begin{abstract}
Pigeonpea is an important crop in semi-arid tropics and sub-tropics. The improvement and utilization of this crop in East Africa can enhance food and nutrition security. A study was carried out to examine variation in biochemical composition (crude protein, total phenols, total flavonoid and total anti-oxidant activity) of 55 pigeonpea genotypes grown in Kabete field station during the long rains of April-September 2017. The experiment was set up in a randomized complete block design with three replications. After harvest, 100g of dry seed samples were collected for biochemical analyses. The biochemical analyses were performed at nutrition platform of Biosciences eastern and central Africa- International Livestock Research Institute (BecA-ILRI) Hub, Nairobi, Kenya. Treatment means were separated based on Tukey test using Genstat, SAS and R software. The genotypes varied significantly (P $\leq 0.05)$ for all the parameters measured with a mean of $20.88 \mathrm{~g} / 100 \mathrm{~g}, 46.21 \mathrm{mg} / 100 \mathrm{~g}, 23.98 \mathrm{mg} / 100 \mathrm{~g}$ and $38.13 \mathrm{mg} / 100 \mathrm{~g}$ for crude protein, total phenol, total flavonoid and total anti-oxidant activity, respectively. Advanced elite materials out performed for all parameters analyzed except for crude protein with a mean of $59.57 \mathrm{mg} / 100 \mathrm{~g}, 26.64 \mathrm{mg} / 100 \mathrm{~g}$ and $30.23 \mathrm{mg} / 100 \mathrm{~g}$ for total phenols, total flavonoid and total antioxidant activity, respectively. The total antioxidant activity had significantly positive correlation $(P \leq 0.05)$ with total phenol, total flavonoid and crude protein. Similarly, total phenol and total flavonoid had significantly positive correlation $(\leq 0.05)$. The results revealed that the advanced elite materials contain high phenolics and antioxidant activity that contribute to lowering oxidation of free radicals due to their redox properties. Therefore, these germplasm are valuable genetic resources for improving pigeonpea varieties for nutritional qualities.
\end{abstract}

Keywords: Biochemicals; elite genotypes; nutritional quality; oxidation; pigeonpea; redox properties.

Abbreviations: ANOVA_Analysis of variance; BSA_Bovine serum albumin; OD_Optical density; RPD_Relative percent difference.

\section{Introduction}

Pigeonpea [Cajanus cajan (L.) Millsp.] is a legume crop mainly grown in the semi-arid tropics (Saxena et al., 2002) where millions of people are living below the poverty line and their livelihood primarily depends on the rain fed agriculture (Choudhary et al., 2013). Pigeonpea is a drought tolerant crop and produces reasonable grain yield during the dry spell when other legumes have dried up. The ability of the pigeonpea to withstand severe drought better than many other legumes is attributed to its deep roots and osmotic adjustment in the leaves (Subbarao et al., 2000).

Pigeonpea is a favorite crop of small holder farmers in dry lands because it provides large amounts of proteins, calories, vitamins, and essential minerals for human nutrition (Saxena et al., 2002). It has been identified as a source of dietary protein mainly in vegetarian based diets (Chitra et al., 1996).
Pigeonpea is among the best solution to protein-calorie malnutrition in the developing world where such malnutrition is persistently a serious challenge among the children leading to physical, mental and motor retardation.

Pigeonpea has the ability to fix atmospheric nitrogen in to the soil at about $40 \mathrm{~kg} / \mathrm{ha}$ per season (Saxena et al., 2002). It can access bound phosphorus in the soil due to presence of piscidic acid in root exudates that solubilize phosphorus in the rhizosphere (Rao et al., 2001). Besides its nutritional value and nitrogen fixing capabilities, pigeonpea also possesses various medicinal properties due to the presence of polyphenols and flavonoids with health benefits. Phenolic compounds such as flavonoids are plant secondary metabolites that play an important role in plant protection (Pal et al., 2011). Although plant phenolics have been classified as anti-nutrients, they are 
useful as natural antioxidants because of their positive correlation with antioxidant activity (Rani et al., 2014). Epidemiological studies have revealed that the consumption of phenolic, flavonoid-rich foods provide protection against human diseases associated with oxidative stress (Wang et al., 2009). Pigeonpea seeds are a good source of antioxidants (AlSaeedi and Hossain, 2015).

As stated earlier, pigeonpea is climate smart legume that plays significant roles in food and nutrition security, human health, soil fertility improvement. Pigeonpea germplasm are genetically diverse and differs in the biochemical properties that determine the nutritive and medicinal values (Al-Saeedi and Hossain, 2015). However, there is little information available on biochemical composition of currently cultivated pigeonpea genotypes in Kenya. Therefore, this study offers first-hand information on biochemicals content in seeds of different pigeonpea genotypes grown in Kenya. This information can be utilized in selecting genotypes with elevated levels of protein and antioxidant potential for enhanced nutritional quality.

\section{Results}

\section{Variation in biochemical composition among 55 pigeonpea genotypes}

The pigeonpea genotypes varied for all four parameters measured (Table 1). Crude protein ranged in between 16.7 and $28.43 \mathrm{~g} / 100 \mathrm{~g}$ with a mean of $20.88 \mathrm{~g} / 100 \mathrm{~g}$ while, total phenols ranged in between 20.15 and $84.44 \mathrm{mg} / 100$ gwith a mean of $46.21 \mathrm{mg} / 100 \mathrm{~g}$. Similarly, total flavonoids content ranged in between 13.88 and $33.48 \mathrm{mg} / 100 \mathrm{~g}$ with a mean of 23.98 $\mathrm{mg} / 100 \mathrm{~g}$. However, a range in between 20.95 and $86.84 \mathrm{mg} / 100$ with mean of $38.13 \mathrm{mg} / 100 \mathrm{~g}$ were measured for total anti-oxidant activity.

Variations in biochemical composition among three groups of pigeonpea genotypes

Variation among the three groups of pigeonpea genotypes (landraces, advanced elite lines, improved cultivars) in crude protein, total phenols, total flavonoids and total anti-oxidant activity was also determined. Crude protein contents did not differ significantly between the groups, advanced genotypes recorded a mean of $20.7 \mathrm{~g} / 100 \mathrm{~g}$ while improved cultivars and landraces recorded 20.5 and $20.3 \mathrm{~g} / 100 \mathrm{~g}$, respectively (Fig 1).

The three group of pigeonpea genotypes differed significantly in total phenols $(P \leq 0.001)$ with the advanced elite lines recording the highest $(59.57 \mathrm{mg} / 100 \mathrm{~g})$ and improved cultivars recording the lowest $(39.72 \mathrm{~g} / 100 \mathrm{mg}$; Fig.2). Similar trend was observed in total flavonoids where the three group of pigeonpea genotypes differed significantly $(P \leq 0.001)$ with advanced elite genotypes recording the highest mean (26.1 $\mathrm{g} / 100 \mathrm{mg})$ and landraces recording the lowest mean $(21.2$ g/100mg; Fig 3).The three group of pigeonpea genotypes exhibited significant variation $(P \leq 0.001)$ in total antioxidant activity. The landraces recorded the highest values (40.26 $\mathrm{mg} / 100 \mathrm{~g}$ ) followed by improved $(32.35 \mathrm{mg} / 100 \mathrm{~g}$ ) and finally advanced genotypes ( $30.23 \mathrm{mg} / 100 \mathrm{~g}$; Fig 4).

\section{Correlation analysis}

Significant correlation was observed in all parameters analyzed with some correlating negatively and others positively. Positive significant correlation was found in total phenols $\left(r=0.141^{* * *}\right)$, total flavonoids $\left(r=0.436^{* *}\right)$, proteins $\left(r=0.219^{*}\right)$ with antioxidant activity and total flavonoids $\left(r=0.125^{* * *}\right)$ with total phenols. However, negative correlation was observed in total phenols $\left(r=-0.528^{* *}\right)$, total flavonoids $\left(r=0.436^{* *}\right)$ with proteins (Table 2).

\section{Discussion}

\section{Crude protein}

Significant variation among the 55 genotypes was observed with a range of $17.48-24.79 \mathrm{~g} / 100 \mathrm{~g}$ and a mean of 20.88 $\mathrm{g} / 100 \mathrm{~g}$ crude protein. The results of this study concur with previous studies that reported crude protein content of 20.5 $\mathrm{g} / 100 \mathrm{~g}$ (Saxena et al., 2010) and $21 \mathrm{~g} / 100 \mathrm{~g}$ (Mohammed et al., 2010). However the crude protein content for genotypes evaluated in this study was lower compared to those reported by another study in Côte d'Ivoire with mean of $25.6 \mathrm{~g} / 100 \mathrm{~g}$ (Digbeu et al., 2018). This variation may be attributed to crop production environment, input used in crop production, seed storage, samples processing methods and presence of polyphenols which affect the activity of digestive enzymes which in turn affect the protein quality (Digbeu et al., 2018).

\section{Total phenol}

The 55 genotypes of pigeonpea differed significantly in total phenols ranging $(20.15-84.44 \mathrm{mg} / 100 \mathrm{~g})$ with a mean of 46.21 $\mathrm{mg} / 100 \mathrm{~g}$. The advanced elite genotypes recorded the highest (59.57 mg/100g) and improved varieties (39.72mg/100mg) recording the lowest. These results are similar to previous findings (Nneka, 2016) who reported total phenolics content of $20.62 \mathrm{mg} / 100 \mathrm{~g}$ in pigeonpea seeds. However, the total phenolic content $(74 \mathrm{mg} / 100 \mathrm{~g})$ of the genotypes evaluated in this study was found to be lower than that reported by (AlSaeedi \& Hossain, 2015). Total phenols are produced naturally during growth and development of plants to protect themselves from biotic and abiotic stresses. The variations in total phenolics content among studies might have been influenced by genotypes, differences in maturity period, storage conditions, processing methods, phytochemical quantification methods, and environmental factors (Panche et al.,2016).

\section{Total flavonoid}

Total flavonoids content was recorded in a range of 13.87 to $33.48 \mathrm{mg} / 100 \mathrm{~g}$ with a mean of $23.98 \mathrm{mg} / 100 \mathrm{~g}$ among the 55 genotypes analyzed in this study. Other studies reported flavonoids content of $8.65 \mathrm{mg} / \mathrm{g}$ (Rani et al., 2014), 8.11 $16 \mathrm{mg} / 100 \mathrm{~g}$ (Nneka, 2016) and $1.14 \mathrm{mg} / 100 \mathrm{~g}$ 
Published under open access licence: CC-BY

Table 1. Biochemical composition of 55 pigeonpea genotypes.

\begin{tabular}{|c|c|c|c|c|c|}
\hline Pigeonpea genotypes & Type & $\begin{array}{l}\text { Crude protein } \\
(\mathrm{g} / 100 \mathrm{~g})\end{array}$ & Total phenols (mg/100g) & $\begin{array}{c}\text { Total flavonoids } \\
(\mathrm{mg} / 100 \mathrm{~g})\end{array}$ & $\begin{array}{c}\text { Total antioxidant activity } \\
(\mathrm{mg} / 100 \mathrm{~g})\end{array}$ \\
\hline ICEAP 00068 & Advanced & $27.977^{b}$ & $60.173^{g}$ & $30.911^{\mathrm{c}}$ & $44.019^{h}$ \\
\hline ICEAP 00554 & Advanced & $28.434^{\mathrm{a}}$ & $55.026^{\mathrm{g}}$ & $33.481^{\mathrm{a}}$ & $38.877^{j}$ \\
\hline ICEAP 00557 & Advanced & $27.785^{c}$ & $52.438^{\mathrm{g}}$ & $31.478^{b}$ & $31.951^{n}$ \\
\hline ICEAP 00902 & Advanced & $23.942^{\prime}$ & $53.771^{g}$ & $25.613^{g}$ & $61.741^{b}$ \\
\hline ICEAP 01147 & Advanced & $22.267^{\circ}$ & $61.423^{\mathrm{g}}$ & $21.431^{\mathrm{m}}$ & $46.526^{\mathrm{g}}$ \\
\hline ICEAP 01147/1 & Advanced & $22.958^{n}$ & $64.709^{f}$ & $25.562^{\mathrm{g}}$ & $31.415^{n}$ \\
\hline ICEAP 01150 & Advanced & $24.492^{j}$ & $63.638^{f}$ & $25.983^{\mathrm{g}}$ & $27.828^{q}$ \\
\hline ICEAP 01150/1 & Advanced & $23.989^{\prime}$ & $59.959^{g}$ & $25.438^{\mathrm{g}}$ & $27.249^{q}$ \\
\hline ICEAP 01154/2 & Advanced & $19.539^{\mathrm{u}}$ & $67.655^{e}$ & $20.173^{n}$ & $26.203^{q}$ \\
\hline ICEAP 01541 & Advanced & $23.410^{\mathrm{m}}$ & $56.904^{g}$ & $22.431^{k}$ & $22.182^{\mathrm{s}}$ \\
\hline ICEAP 00979/1 & Advanced & $26.238^{\dagger}$ & $64.210^{\dagger}$ & $27.062^{\mathrm{g}}$ & $19.281^{t}$ \\
\hline ICEAP 01159 & Advanced & $26.637^{e}$ & $43.072^{j}$ & $30.210^{d}$ & 34.956 \\
\hline ICEAP 01179 & Advanced & $20.229^{5}$ & $26.212^{n}$ & $19.613^{p}$ & $57.227^{d}$ \\
\hline ICEAP 00911 & Advanced & $23.961^{\prime}$ & $82.769^{b}$ & $25.057^{h}$ & $48.418^{f}$ \\
\hline КАТ $60 / 8$ & Improved & $19.344^{v}$ & $47.829^{h}$ & $17.477^{t}$ & $39.029^{j}$ \\
\hline ICEAP 00850 & improved & $19.004^{v}$ & $65.978^{f}$ & $17.812^{s}$ & $82.569^{a}$ \\
\hline ICEAP 00550 & improved & $24.897^{i}$ & $52.446^{\mathrm{g}}$ & $27.346^{\mathrm{g}}$ & $27.540^{q}$ \\
\hline ICEAP 00932 & improved & $22.490^{\circ}$ & $78.988^{c}$ & $25.460^{\mathrm{g}}$ & $40.861^{i}$ \\
\hline ICEAP 00933 & improved & $22.408^{\circ}$ & $72.131^{d}$ & $23.422^{j}$ & $30.318^{\circ}$ \\
\hline ICEAP 00936 & improved & $23.468^{m}$ & $84.445^{a}$ & $25.451^{\mathrm{g}}$ & $20.359^{5}$ \\
\hline ICEAP 01145 & improved & $25.591^{\mathrm{g}}$ & $58.322^{\mathrm{g}}$ & $26.427^{g}$ & $42.186^{i}$ \\
\hline ICEAP 01155 & improved & $24.389^{j}$ & $59.439^{g}$ & $24.069^{i}$ & $39.405^{j}$ \\
\hline ICEAP 01157 & improved & $28.116^{b}$ & $53.647^{g}$ & $29.614^{\mathrm{e}}$ & $46.415^{\mathrm{g}}$ \\
\hline ICEAP 01160 & improved & $25.972^{\mathrm{g}}$ & $42.427^{j}$ & $28.963^{\dagger}$ & $33.056^{m}$ \\
\hline ICEAP 01161 & improved & $24.459^{j}$ & $30.318^{n}$ & $26.058^{g}$ & $41.068^{i}$ \\
\hline ICEAP 01162 & improved & $19.951^{\mathrm{t}}$ & $47.713^{h}$ & $19.431^{p}$ & $22.191^{\mathrm{s}}$ \\
\hline ICEAP 01164 & improved & $25.522^{\mathrm{g}}$ & $44.954^{i}$ & $26.078^{g}$ & $48.191^{f}$ \\
\hline ICEAP 01166/2 & improved & $25.7075^{\mathrm{g}}$ & $34.612^{m}$ & $27.451^{\mathrm{g}}$ & $49.265^{f}$ \\
\hline ICEAP 01167 & improved & $20.717^{r}$ & $32.506^{m}$ & $19.500^{p}$ & $35.256^{1}$ \\
\hline ICEAP 01169 & improved & $25.092^{\mathrm{h}}$ & $37.847^{k}$ & $27.623^{g}$ & $21.081^{\mathrm{s}}$ \\
\hline ICEAP 01170 & improved & $26.292^{f}$ & $34.203^{m}$ & $29.512^{\mathrm{e}}$ & $46.214^{\mathrm{g}}$ \\
\hline ICEAP 01172/2 & improved & $19.685^{u}$ & $27.841^{n}$ & $18.842^{r}$ & $38.976^{j}$ \\
\hline ICEAP 01175 & improved & $19.234^{v}$ & $24.808^{n}$ & $17.286^{t}$ & $34.157^{\prime}$ \\
\hline ICEAP 01181 & improved & $19.797^{u}$ & $23.392^{n}$ & $20.390^{n}$ & $38.103^{j}$ \\
\hline ICEAP 01514/15 & improved & $20.939^{q}$ & $29.707^{n}$ & $20.193^{n}$ & $20.825^{s}$ \\
\hline ICEAP 01525 & improved & $22.946^{n}$ & $28.588^{n}$ & $24.924^{h}$ & $46.387^{g}$ \\
\hline ICEAP 01528 & improved & $18.174^{x}$ & $26.265^{n}$ & $17.831^{\mathrm{s}}$ & $27.914^{q}$ \\
\hline ICEAP 01529 & improved & $22.365^{\circ}$ & $25.036^{n}$ & $20.212^{n}$ & $35.371^{\prime}$ \\
\hline ICEAP 01530 & improved & $24.171^{k}$ & $23.939^{n}$ & $25.771^{\mathrm{g}}$ & $43.871^{h}$ \\
\hline ICEAP 01531 & improved & $24.807^{i}$ & $33.623^{m}$ & $27.286^{\mathrm{g}}$ & $46.946^{g}$ \\
\hline ICEAP 01534 & improved & $25.771^{\mathrm{g}}$ & $36.155^{\prime}$ & $25.627^{g}$ & $41.651^{i}$ \\
\hline ICEAP 01535 & improved & $25.169^{h}$ & $23.112^{n}$ & $26.789^{g}$ & $36.671^{k}$ \\
\hline ICEAP 01536 & improved & $25.834^{g}$ & $26.917^{n}$ & $26.311^{\mathrm{g}}$ & $37.081^{k}$ \\
\hline ICEAP 01537 & improved & $27.285^{d}$ & $22.504^{n}$ & $29.883^{\mathrm{e}}$ & $57.693^{d}$ \\
\hline ICEAP 01538 & improved & $21.340^{p}$ & $23.541^{n}$ & $22.141^{\prime}$ & $21.908^{s}$ \\
\hline ICEAP 01544/2 & improved & $26.729^{e}$ & $55.256^{\mathrm{g}}$ & $29.739^{e}$ & $23.103^{s}$ \\
\hline ICEAP 87105 & improved & $26.037^{g}$ & $63.655^{f}$ & $27.825^{g}$ & $24.919^{r}$ \\
\hline ICPL 7035W & improved & $18.846^{w}$ & $23.982^{n}$ & $17.225^{t}$ & $28.971^{p}$ \\
\hline ICPL 86012 & improved & $16.703^{z}$ & $21.983^{n}$ & $13.883^{v}$ & $27.030^{9}$ \\
\hline ICPL 87091 & improved & $19.341^{v}$ & $20.151^{\circ}$ & $17.866^{\mathrm{s}}$ & $51.518^{\mathrm{e}}$ \\
\hline UGACC 22 & Landrace & $20.709^{r}$ & $56.608^{\mathrm{g}}$ & $19.894^{\circ}$ & $34.908^{\prime}$ \\
\hline ICEAP 00540 & Landrace & $23.396^{m}$ & $53.322^{\mathrm{g}}$ & $25.445^{\mathrm{g}}$ & $44.334^{h}$ \\
\hline ICEAP 00777 & Landrace & $21.202^{p}$ & $52.431^{g}$ & $21.647^{m}$ & $43.732^{h}$ \\
\hline Mthawajuni & Landrace & $20.071^{t}$ & $68.317^{e}$ & $19.118^{q}$ & $50.780^{e}$ \\
\hline$M Z 2 / 9$ & Landrace & $17.765^{y}$ & $60.721^{\mathrm{g}}$ & $16.423^{\mathrm{u}}$ & $59.388^{c}$ \\
\hline Mean & & 20.883 & 46.21 & 23.980 & 38.131 \\
\hline CV\% & & 2.790 & 3.170 & 3.530 & 3.4300 \\
\hline Tukey's HSD & & 0.150 & 2.270 & 0.250 & 1.0500 \\
\hline
\end{tabular}

Note: Values are mean of three replicates and Tukey-test $(p<0.05)$ was used to separate the treatment means.

Table 2. Correlation analysis for biochemical composition

\begin{tabular}{|c|c|c|c|c|}
\hline $\begin{array}{l}\text { Parameters } \\
\text { Phenols }\end{array}$ & $\begin{array}{c}\text { Phenols } \\
1\end{array}$ & Flavonoids & Proteins & Antioxidant \\
\hline Flavonoids & $0.125^{* * *}$ & 1 & & \\
\hline Proteins & $-0.528 * *$ & $-0.408 * *$ & 1 & \\
\hline Antioxidant & $0.141^{* *}$ & $0.436 * *$ & $0.219 *$ & 1 \\
\hline
\end{tabular}

${ }^{*}=$ significant at $\mathrm{P} \leq 0.05,{ }^{* *}=(\mathrm{P} \leq 0.01) \&{ }^{* * *}=(\mathrm{P} \leq 0.001)$. 


\section{Type}

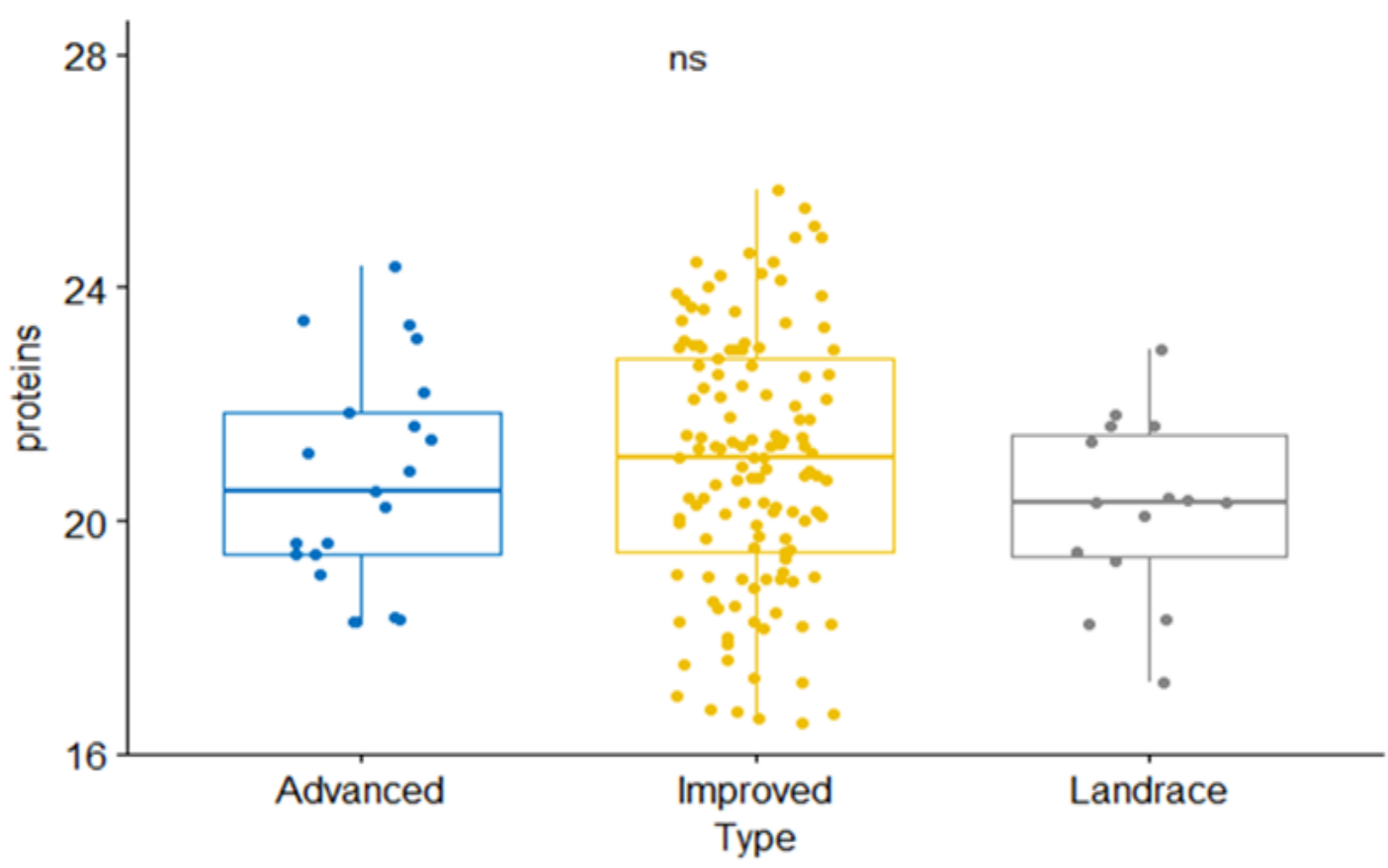

Fig 1. Box plots for crude proteins means $(g / 100 g)$, $n s=$ not significant $(P>0.05)$.

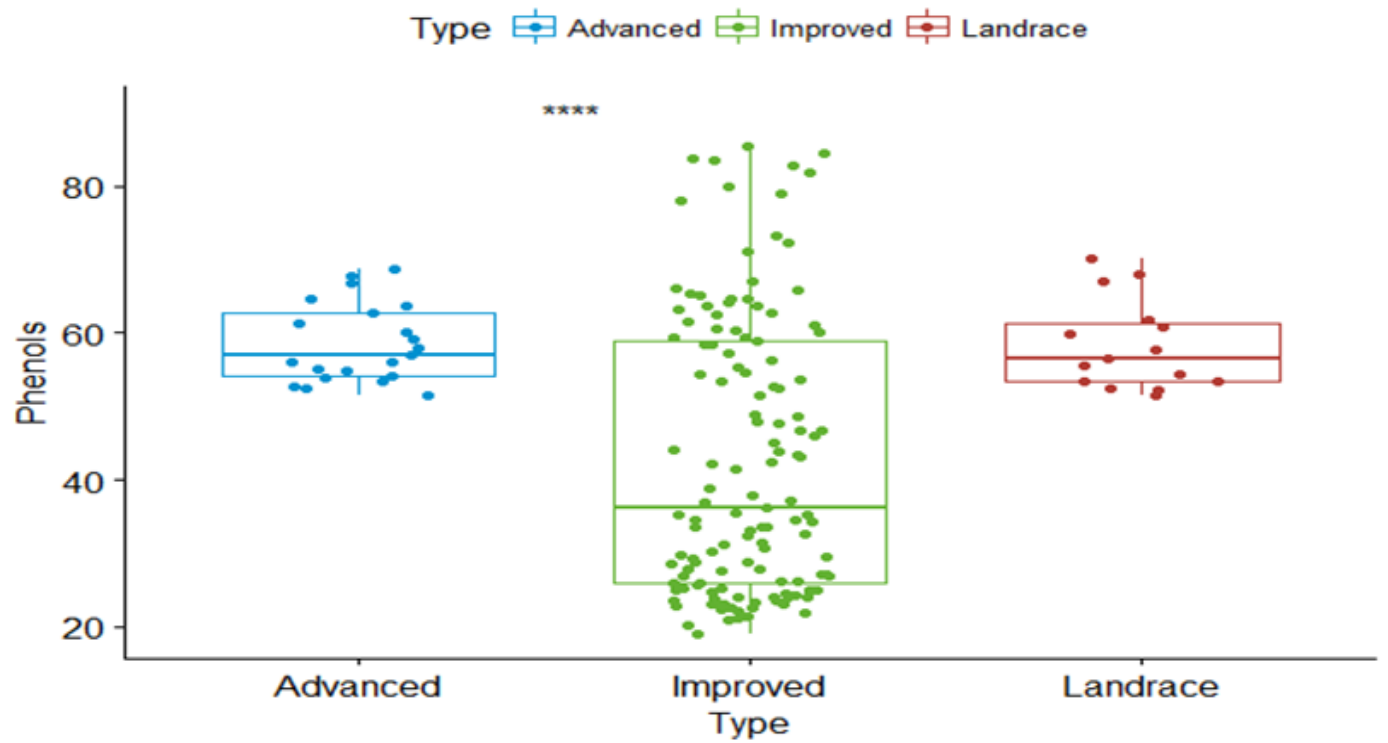

Fig 2. Box plots for total phenols means (mg/100g as gallic acid equivalent), $* * * *=$ significant at $P \leq 0.001$. 
Published under open access licence: CC-BY

Type

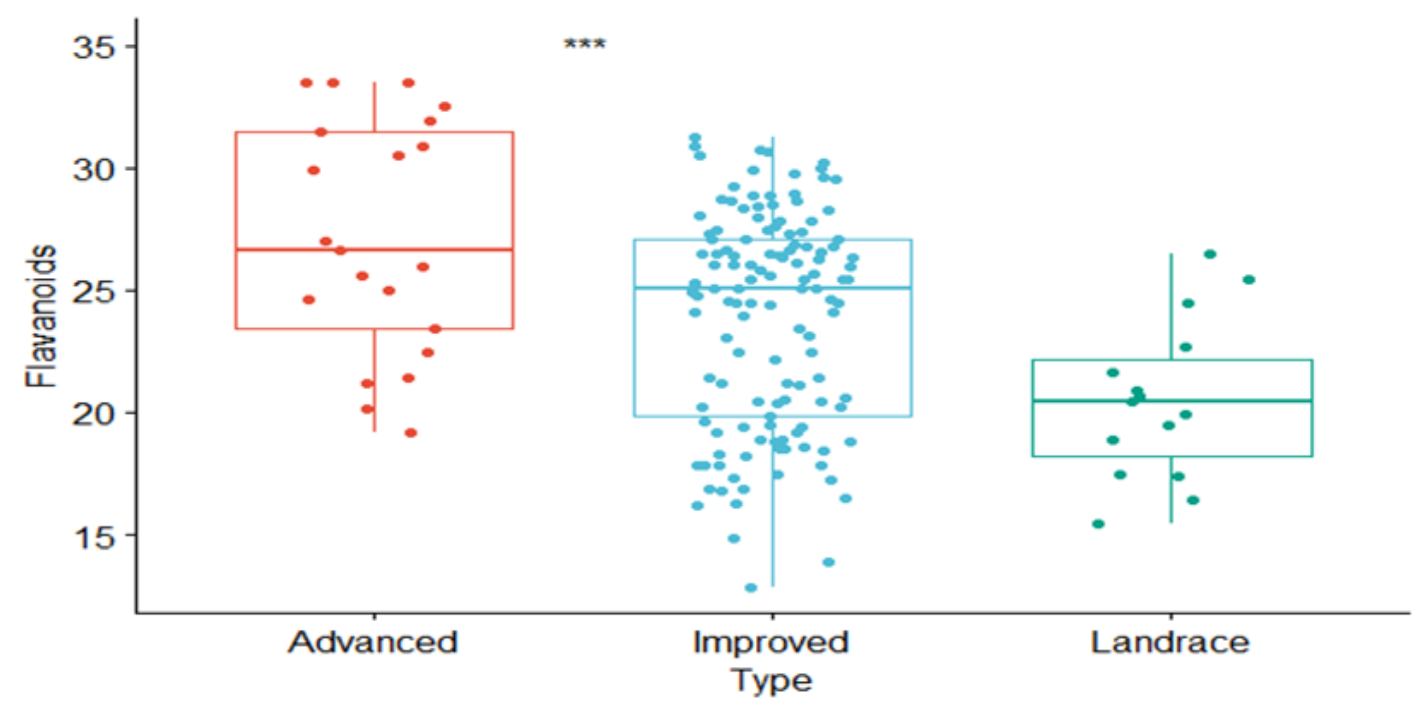

Fig 3. Box plots for total flavonoids means (mg/100g as catechin equivalent), ${ }^{* *}=$ significant at $\mathrm{P} \leqslant 0.001$.

\section{Type $\epsilon_{i}$ Advanced $E_{i}$ Improved $E_{i}$ Landrace}

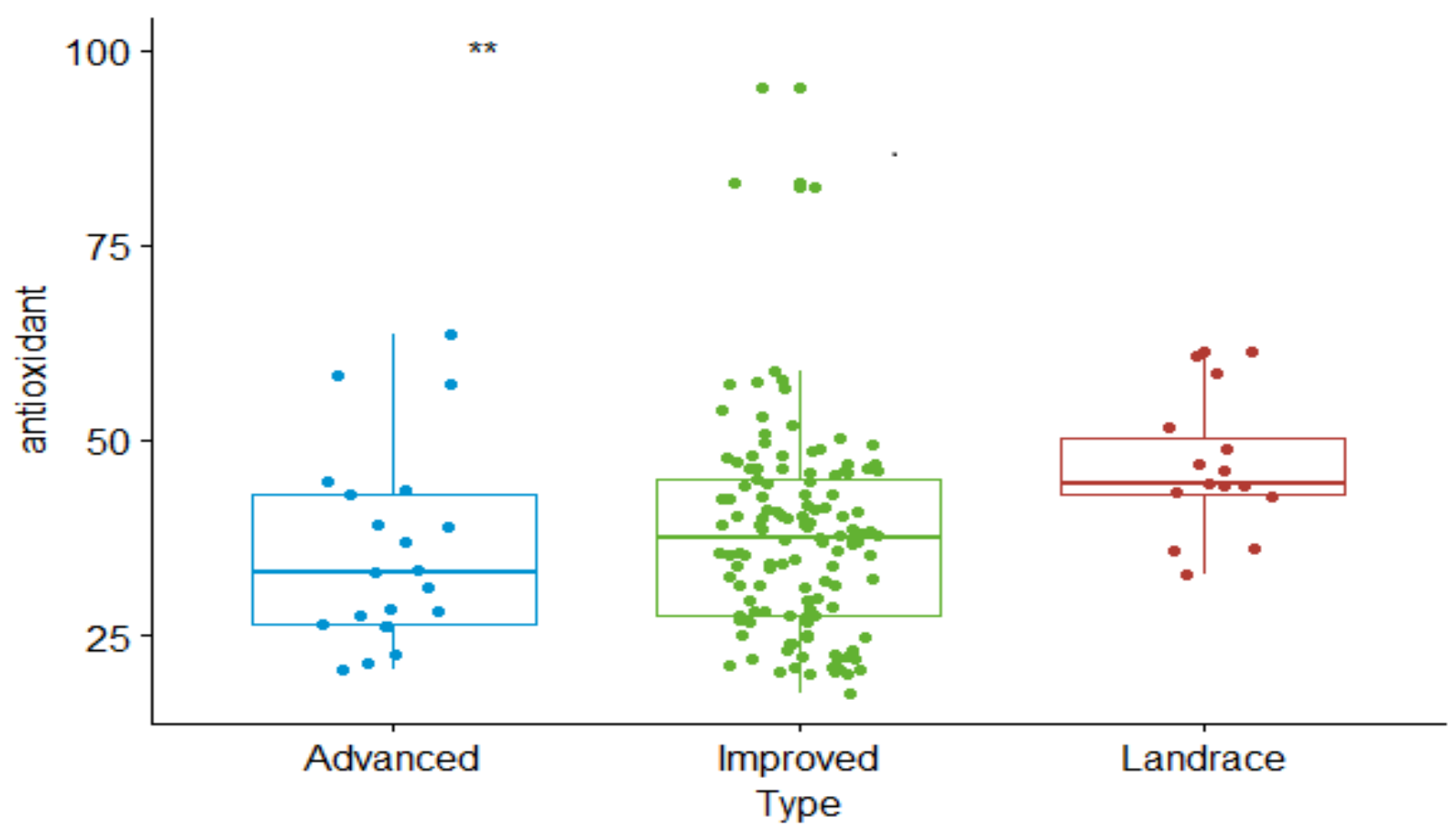

Fig 4. Box plots for total antioxidant activity (mg/100g as Trolox equivalent), $* *=$ significant at $\mathrm{P} \leq 0.01$. 
Al-Saeed and Hossain, 2015). Variations in total flavonoids content may be due to varied levels of flavonols, flavones, anthocyanidins, catechins, flavanones, and isoflavones in the tested genotypes and sample processing methods (Panche et al. , 2016).

\section{Total anti-oxidant activity}

Antioxidant activity of 55 pigeonpea genotypes ranged in between 20.95 to $86.84 \mathrm{mg} / 100 \mathrm{~g}$ and with a mean of 38.13 $\mathrm{mg} / 100 \mathrm{~g}$. Similar trend was observed with three types of pigeonpea genotypes: the landraces recorded the highest values $(40.26 \mathrm{mg} / 100 \mathrm{~g})$ followed by improved varieties $(32.35$ $\mathrm{mg} / 100 \mathrm{~g}$ ) and advanced elite genotypes (30.23 mg/100g). These findings are in agreement with previous studies ( AlSaeedi and Hossain, 2015; Rani et al., 2014). However, a study that analyzed the biscuits prepared from germinated and ungerminated pigeonpea seeds reported higher mean total antioxidant activity (Nneka, 2016). Therefore, antioxidant property results from contribution of phenolic compounds which is mainly due to their redox properties which allow them to act as reducing agents, hydrogen donors and singlet oxygen quenchers (Tapiero et al., 2002). Similarly, phenolic structures play an important role in bioactive activities. The number and location of hydroxyl groups in phenolic structures are linked to antioxidant activity. Levels of antioxidant activity depend on both concentration and types of phenolics present.

\section{Correlation analysis for biochemical components}

Correlation between traits is of great importance for the success of selection practiced in the breeding programs. In this study, the positive correlation between phenolic composition and antioxidant activity shows that total phenol and total flavonoid contents may be important contributors to the antioxidant activity (Stratil et al., 2006). A study on germinated and cooked pulses also reported a positive correlation between total phenols and antioxidant activity (Gujral, 2011). This explains that although plant phenolics have been classified as anti-nutrients, they are useful as natural antioxidants (Bouaziz et al., 2005). Human health is affected by free radicals which play an important role to human health by triggering different chronic diseases like hypertension, diabetes, cancer and heart diseases. Epidemiological studies have shown an inverse association between the risk of chronic human diseases and the consumption of phenolic rich diet (Pandey and Rizvi, 2009). The phenolic groups can accept an electron from relatively stable phenoxyl radicals, thereby distrupting chain oxidation reactions in cellular components by delaying or inhibiting oxidation process (Khanum et al., 2015). Total phenolics are naturally produced during the growth and development of plants to protect them from biotic stresses (Khang et al., 2016). Availability of genotypes with elevated levels of polyphenols and antioxidant activity help to reduce the occurrences of diseases.

\section{Materials and methods}

\section{Plant materials}

Fifty-five pigeonpea genotypes were received from the International Crops Research Institute for the Semi-Arid Tropics (ICRISAT), Nairobi. The field trials were carried out in Kabete Field Station of the University of Nairobi, Kenya during the long rains (April-September) of 2017. These 55 genotypes were composed of 5 landraces, 14 advanced elite lines and 36 improved cultivars. After harvest, $100 \mathrm{~g}$ of dry seed samples were collected for crude proteins, total phenols, total flavonoids, and total antioxidant activity analyses. The biochemical analyses were performed at nutrition platform of Biosciences eastern and central Africa- International Livestock Research Institute (BecA-ILRI) Hub, Nairobi, Kenya.

\section{Sample preparation}

Pigeonpea seed samples were milled into fine homogenous state using CT 193 Cyclotec $^{\text {TM }}$ Sample Mill. Milled samples were analyzed for crude protein, total phenol, total flavonoid, and total antioxidant activity using standard operating procedures described below.

\section{Determination of crude protein}

Crude protein analysis was based on Folin-Lowry method (Lowry et al.,1951) with minor modifications. Approximately $100 \mathrm{mg}$ of dried seed samples was weighed in triplicate into 15 $\mathrm{ml}$ Falcon tubes, $5 \mathrm{ml}$ of $5 \%$ Sodium Dodecyl Sulfate (SDS) was added, vortexed and incubated for 2 hours at room temperature and centrifuged at $2000 \mathrm{rpm}$ for 10 minutes. One hundred micro-litre supernatant was aliquoted into $2 \mathrm{ml}$ Eppendorf tube and added with $1900 \mu$ of distilled water to a final volume of $2000 \mu \mathrm{l}$. Twenty micro-litre of the diluted extract and bovine serum albumin standard $(20-100 \mu \mathrm{g} / \mathrm{ml})$ was aliquoted into respective wells in a 96 well micro-titre plate in duplicates. To each of the sample and standard, $100 \mu \mathrm{l}$ of reagent $A$ (Copper-tartrate-carbonate reagent, 5\% SDS, 0.8M $\mathrm{NaOH}$ and $\left.\mathrm{dH}_{2} \mathrm{O}\right)$ and $50 \mu \mathrm{l}$ of reagent $\mathrm{B}(0.4 \mathrm{~N}$ Folin-Ciocalteu phenol) was added to each well after 20 seconds with gentle priming. The solution was incubated at room temperature for 30 minutes for colour development. Absorbance/optical density (OD) readings were obtained at $630 \mathrm{~nm}$ using a BioTek Synergy-HT (Vermont, USA) micro-titer plate reader. The average $O D$ for the two readings of the standards were calculated and used for linear regression analysis. The OD standards and their corresponding protein concentrations were plotted to obtain a linear calibration curve $\left(r^{2} \geq 0.98\right)$ and determine the protein concentration of the test samples.

For quality control purposes BCR 708, a certified reference sample from the Institute for Reference Materials and Measurement, Joint Research Center of the European Commission was included in the analysis. The test samples 
falling outside the expected range were retested. The relative percent difference (RPD) of each sample was calculated from the duplicate OD readings and samples with RPD values $>10 \%$ was retested.

\section{Determination of total phenol}

Total phenols were determined following Folin-Ciocalteu method with minor modifications (Kujala et al., 2000). A total of $0.4 \mathrm{~g}$ of the milled samples was weighed in a $50 \mathrm{ml}$ Falcon tube and added with $10 \mathrm{ml}$ of the $80 \%$ methanol. The samples were incubated for 24 hours on a mechanical shaker at $25^{\circ} \mathrm{C}$. The mixture was then centrifuged at $4,000 \mathrm{rpm}$ for 10 minutes; the supernatant was aliquoted for determination of the total phenolic contents in a 96 well micro-titer plate. Upon adding $20 \mu \mathrm{l}$ of the samples/blank/standards and $100 \mu \mathrm{l}$ of FolinCiocalteu phenol reagent in duplicates at the respective wells, the solution was mixed gently by priming and after 5 minutes, $80 \mu \mathrm{l}$ of $7 \% \mathrm{Na}_{2} \mathrm{CO}_{3}$ was added with gentle priming. The plate was covered with an aluminum foil and the reaction was incubated at room temperature for 90 minutes for colour development. The resulting blue colour was measured using BioTek Synergy-HT (Vermont, USA) at $725 \mathrm{~nm}$. External calibration was used for quantification of total phenolics as their corresponding gallic acid equivalent.

The average $O D$ for the two readings of the gallic acid standards $(10-100 \mu \mathrm{g} / \mathrm{ml})$ were calculated and used for linear regression analysis. The obtained OD standards versus their corresponding gallic acid concentrations were plotted to prepare a linear calibration curve $\left(r^{2} \geq 0.98\right)$. The RPD between two readings was calculated as described for total phenolics. The total phenolic content was determined after dilution factor correction and expressed as mg gallic acid equivalent per 100 grams of dry sample.

\section{Determination of total flavonoids}

The total flavonoid content was determined using Aluminum chloride colorimetric procedure (Kujala et al., 2000; Zhishen et al.,1999). A total of $0.4 \mathrm{~g}$ of the milled samples was weighed into clean $50 \mathrm{ml}$ Falcon tubes and added with $10 \mathrm{ml}$ of the $80 \%$ methanol. The samples were incubated on a mechanical shaker at $25{ }^{\circ} \mathrm{C}$ for 24 hours. The mixture was then centrifuged at $4,000 \mathrm{rpm}$ for 10 minutes then the supernatant was aliquoted for determination of the total flavonoid contents. Then $20 \mu \mathrm{l}$ of sample extracts or standard solution of catechin $(10-100 \mu \mathrm{g} / \mathrm{ml})$ was aliquoted in duplicate into respective wells of the micro-titer plate, $80 \mu \mathrm{l}$ of $\mathrm{ddH}_{2} \mathrm{O}$ was added followed by addition of $10 \mu \mathrm{l} 5 \% \mathrm{NaNO}_{2}$ with gentle priming. After 5 minutes, $10 \mu \mathrm{l}$ of $10 \% \mathrm{AlCl}_{3}$ was added and gently mixed by priming. After another 5 minutes, $80 \mu \mathrm{l}$ of $2 \mathrm{M} \mathrm{NaOH}$ was added and gently mixed by priming. The reaction was incubated at room temperature for 30 minutes and the absorbance of the samples and standards was measured using a BioTek Synergy-HT (Vermont, USA) microplate reader at a wavelength of $510 \mathrm{~nm}$.

The average OD for the two readings of the catechin standards $(10-100 \mu \mathrm{g} / \mathrm{ml})$ were calculated and used for linear regression analysis. The obtained standards OD versus their corresponding catechin acid concentrations were plotted to prepare a linear calibration curve $\left(r^{2} \geq 0.98\right)$. The relative percent difference (RPD) for each sample was calculated from two OD readings. Sample with RPD value greater than $10 \%$ were retested. The total flavonoid content was determined after dilution factor correction and the results expressed as $\mathrm{mg}$ of catechin equivalent per $100 \mathrm{~g}$ of dry sample.

\section{Determination of total antioxidant activity}

Antioxidant activity was determined using DPPH procedure using Trolox as the standards (Shalaby \& Shanab, 2013). The extract prepared for analysis of phenols was used for this assay in a 96 well micro-titre plate. Into the plate, $50 \mu \mathrm{l}$ of test samples, Trolox standards $(10-100 \mu \mathrm{g} / \mathrm{ml})$ and blank were pippeted followed by addition of $50 \mu \mathrm{l}$ of $60 \mathrm{mM}$ DPPH in duplicates. The plates were shaken gently using plate shaker and incubated for 20 minutes. The absorbance was measured in a BioTek Synergy-HT (Vermont, USA) micro-titer plate reader at wave length of $515 \mathrm{~nm}$.

The average OD for the two readings of the Trolox standards $(10-100 \mu \mathrm{g} / \mathrm{ml})$ were calculated and used for linear regression analysis. The obtained standards OD versus their corresponding Trolox concentrations were plotted to prepare a linear calibration curve $\left(r^{2} \geq 0.98\right)$. The RPD for each sample was calculated from two OD readings, and samples where the RPD was greater than $10 \%$ were retested. The total antioxidant activity was determined by adjusting dilution factor and results were expressed in $\mathrm{mg}$ of Trolox equivalent per $100 \mathrm{~g}$ of dry sample.

\section{Correlation analysis}

Correlation analysis was undertaken to determine the association effect among crude protein, total phenols, total flavonoids and total antioxidant activity.

\section{Statistical analysis}

Three replicates of each sample were used for statistical analysis and resulting values were expressed as mean. Oneway analysis of variance (ANOVA) and F-test were carried out using both Genstat version 14 and R soft wares and Tukey test was used to assess the differences between the means at $95 \%$ confidence level $(P \leq 0.05)$. Correlation analyses of biochemical components were carried out using Pearson correlation programme in SAS.

\section{Conclusion}

This study shows variations among test genotypes for total phenolic, total flavonoid contents and total antioxidant activity exhibiting utility of these genetic resources for improving nutritional qualities of pigeonpea. As in other crop species, the environment may have significant role in biochemical composition of pigeonpea, suggesting needs for multilocation evaluations of these genotypes to examine effect of genotype $x$ environment interaction on nutritional qualities. We suggest further research with large number of pigeonpea genotypes for yield and nutritional qualities. The information generated through this research would be useful in developing pigeonpea varieties in Kenya. 


\section{Conflicts of interest}

The authors declare that they have no competing interests

\section{Acknowledgement}

This project was supported by the BecA-ILRI Hub through the Africa Biosciences Challenge Fund ( $A B C F$ ) program. The ABCF Program is funded by the Australian Department for Foreign Affairs and Trade (DFAT) through the BecA-CSIRO partnership; the Syngenta Foundation for Sustainable Agriculture (SFSA); the Bill \& Melinda Gates Foundation (BMGF); the UK Department for International Development (DFID) and; the Swedish International Development Cooperation Agency (SIDA). Support from National Research Fund Kenya and University of Eldoret annual grants is also recognized for supporting field work.

\section{References}

Al-Saeedi AH, Hossain MA (2015) Total phenols, total flavonoids contents and free radical scavenging activity of seeds crude extracts of pigeon pea traditionally used in Oman for the treatment of several chronic diseases. Asian Pac J Trop Dis. 5: 316-321.

Bouaziz M, Grayer RJ, Simmonds MSJ, Damak M, Sayadi S (2005) Identification and antioxidant potential of lavonoids and low molecular weight phenols in olive cultivar chemlali growing in Tunisia. J Agric Food Chem. 53: 236-241.

Chitra U, Singh U, Venkateswara Rao P (1996) Phytic acid, in vitro protein digestibility, dietary fiber, and minerals of pulses as influenced by processing methods. Plant Foods Hum Nutr. 49: 307-316.

Choudhary a K, Raje R S, Subhojit D, Rafat S, Timmanna O, Saha S (2013) Conventional and molecular approaches towards genetic improvement in pigeonpea for insects resistance. American J Plant Sci. 4: 372-385.

Digbeu YD, Blei HS, Mankambou JG, Dué EA, Kouakou B (2018) Nutritionnel assessment of Cajanus cajan seeds from Côte D'ivoire. Saudi J Biomed Res. 3: 44-49.

Khang D, Dung T, Elzaawely A, Xuan T (2016) Phenolic profiles and antioxidant activity of germinated legumes. Foods. 5(2): 27- 35.

Khanum R, Mazhar F, Jahangir M (2015) Antioxidant evaluations of polar and non-polar fractions of Cajanus cajan seeds. J Med Plant Res. 9: 193-198.

Kujala TS, Loponen JM, Klika KD, Pihlaja K (2000) Phenolics and betacyanins in red beetroot (Beta vulgaris) root: distribution and effect of cold storage on the content of total phenolics and three individual compounds. J Agric and Food Chem. 48: 5338-42.

Lowry O, Rosebrough N, Farr A, Randall R (1951) Protein measurement with folin phenol reagent. J Biological Chem. 193: $265-275$.
Mohammed EARS, Ali AO, Haron R (2010) The chemical composition of Pigeon pea (Cajanus cajana) seed and functional properties of protein isolate. Pak J Nutriti. 9: 1069-1073.

Nneka UN (2016) Effect of heat on antioxidants, its activity and acceptability of biscuit made from germinated pigeon pea flou. Int J Food Sci and Nutri.1: 01-05.

Pal D, Mishra P, Sachan N, Ghosh AK (2011) Biological activities and medicinal properties of Cajanus cajan (L) Millsp. J Advanced Pharm Tech Res. 2: 207-14.

Panche AN, Diwan AD, Chandra SR (2016) Flavonoids: an overview. J Nutri Sci. 5: 1-15.

Pandey KB, Rizvi SI (2009) Plant polyphenols as dietary antioxidants in human health and disease. Oxid Med Cell Longev. 2:270-278.

Pele GI, Oladiti EO, Bamidele PO, Fadipe E (2016) Influence of processing techniques on the nutritional and anti-nutritional properties of Pigeon pea (Cajanus cajan). Int J Eng App Sci. 3: 92-94.

Rani S, Poswal G, Yadav R, Deen MK (2014) Screening of Pigeonpea (Cajanus cajan L.) seeds for study of their flavonoids, total phenolic content and antioxidant properties. Int J Pharm Sci Rev Res. 28: 90-94.

Rao KJVDK, Johansen C, Chauhan YS, Jain VK, Jain KC, Talwar HS (2001) An analysis of yield variation among long-duration pigeonpea genotypes in relation to season, irrigation and plant population. J Agric Sci. 136: 291-299.

Saxena KB, Kumar RV, Sultana R (2010) Quality nutrition through pigeonpea-a review. Health. 2: 1335-1344.

Saxena K B, Kumar R V, Rao P V (2002). Pigeonpea nutrition and its improvement. J Crop Prod. 5: 227-260.

Shalaby EA, Shanab SMM (2013) Comparison of DPPH and ABTS assays for determining antioxidant potential of water and methanol extracts of Spirulina platensis. Indian J Marine Sci. 42: 556-564.

Singh Gujral H, Angurala M, Sharma P Singh J (2011) Phenolic content and antioxidant activity of germinated and cooked pulses. Inter J Food Properties. 14: 1366-1374.

Stratil P, Klejdus B, Kuban V (2006) Determination of total content of phenolic compounds and their antioxidant activity in vegetables;Evaluation of spectrophotometric methods. J Agric Food Chem. 54: 607-616.

Subbarao GV, Nguyen HM, Chauhan Y S, Johansen C (2000) Patterns of osmotic adjustment. Euro J Agron. 12: 239-249.

Tapiero H, Tew KD, Ba GN, Mathé G (2002) Polyphenols: do they play a role in the prevention of human pathologies? Biomed Pharmacotherapy. 56: 200-207.

Wang L, Lee IM, Zhang SM, Blumberg JB, Buring JE, Sesso HD (2009) Dietary intake of selected flavonols, flavones, and flavonoid-rich foods and risk of cancer in middle-aged and older women. Am J Clinical Nutr. 89: 905-12.

Zhishen J, Mengcheng T, Jianming W (1999) The determination of flavonoid contents in mulberry and their scavenging effects on superoxide radicals. Food Chem. 64: 555-559. 